\title{
Molecular characterization of the her-1 gene suggests a direct role in cell signaling during Caenorhabditis elegans sex determination
}

\author{
Marc D. Perry, ${ }^{1}$ Weiqing Li, ${ }^{1}$ Carol Trent, ${ }^{1,2}$ Barbara Robertson, ${ }^{1}$ Andrew Fire, ${ }^{3}$ Judith $M$. \\ Hageman, ${ }^{1}$ and William B. Wood ${ }^{1}$ \\ ${ }^{1}$ Department of Molecular, Cellular, and Developmental Biology, University of Colorado, Boulder, Colorado 80309-0347 \\ USA; ${ }^{2}$ Department of Biology, Western Washington University, Bellingham, Washington 98225 USA; $^{3}$ Carnegie Institution \\ of Washington, Department of Embryology, Baltimore, Maryland 21210 USA
}

\begin{abstract}
We have characterized two transcripts from the male-determining her-1 locus in Caenorhabditis elegans. The larger transcript, which appears more important for male development, is predicted to encode a novel 175-amino-acid, cysteine-rich polypeptide with an apparent amino-terminal signal sequence and potential cleavage and glycosylation sites. Expression of a full-length cDNA construct for the larger transcript driven by a body-wall-myosin promoter causes extensive masculinization of all sexually dimorphic tissues in XX (normally hermaphrodite) animals. This activity is dependent on the presence of the her-1 signal sequence or a substitute synthetic signal sequence in the encoded polypeptide. These results suggest that a secreted product of the her-1 gene dictates male development.
\end{abstract}

[Key Words: Cell interactions; nematodes; signal transduction; transmembrane signaling]

Received September 21, 1992; revised version accepted December 15, 1992.

The primary signal for sex determination in Caenorhabditis elegans is the ratio of $\mathrm{X}$ chromosomes to autosomes (X/A ratio) (Nigon 1951; Madl and Herman 1979). Genotypes of $\mathrm{XO}(\mathrm{X} / \mathrm{A}=0.5)$ and $\mathrm{XX}(\mathrm{X} / \mathrm{A}=1.0)$ normally dictate male and hermaphrodite development, respectively. The two sexes show extensive dimorphism in most tissues: For example, males have a unilobed testis connected to the cloaca and a complex tail specialized for copulation, whereas hermaphrodites, which are selffertile, have a bilobed ovotestis connected to the vulva and a simpler tail (for review, see Hodgkin 1988). Genetic analysis has shown that the primary signal is interpreted through a regulatory cascade (Fig. 1) including seven autosomal genes that control somatic as well as germ-line sex determination (for review, see Hodgkin 1987; Hodgkin 1990) and three X-linked genes that regulate both these genes and the genes that mediate $X$ chromosome dosage compensation (for review, see Villeneuve and Meyer 1990). Although molecular information on some of the corresponding gene products has recently become available (see above reviews and Discussion|, the nature of the cascade and its relationship to other known developmental regulatory pathways is not yet clear.

The her-1 gene, which is necessary for normal male development in XO animals (Hodgkin 1980), appears to be the point at which the $\mathrm{X}$-linked regulatory genes con- trol sex determination. The activity of her-1, in turn, controls activity of the terminal regulator tra-1 as shown in Figure 1, via tra-2, tra-3, and the fem genes, so that in an XO animal tra-1 function is repressed and male development is permitted. The her-1 gene is defined by 25 loss-of-function (lf) mutations; most of these result in complete transformation of XO animals into self-fertile hermaphrodites and have no effect on XX animals (Hodgkin 1980; Trent et al. 1988). Weak If alleles can result in variably transformed intersexual XO animals. Two dominant gain-of-function $(g f)$ mutations at the her-1 locus (n695 and y101) result in the opposite phenotype: XX animals are variably transformed (masculinized) into pseudomales (Trent et al. 1983, 1988, 1991). This dominant phenotype shows that her-1 expression in $\mathrm{XX}$ animals is sufficient to activate much of the male developmental program.

Trent et al. (1991) cloned the her-1 gene and identified two colinear her-1 transcripts present in XO and virtually absent in XX animals, a relatively rare 1.2-kb mRNA and a relatively abundant 0.8 - $\mathrm{kb}$ mRNA. Both transcripts were shown to be present in $\mathrm{XX}$ animals carrying either of the her-1 $(g f)$ alleles or a partial lf mutation in either $s d c-1$ or $s d c-2$, indicating that these genes act to control her-1 transcript levels.

Mosaic analysis reported by Hunter and Wood (1992) demonstrated that her-1 or a gene under its control can 


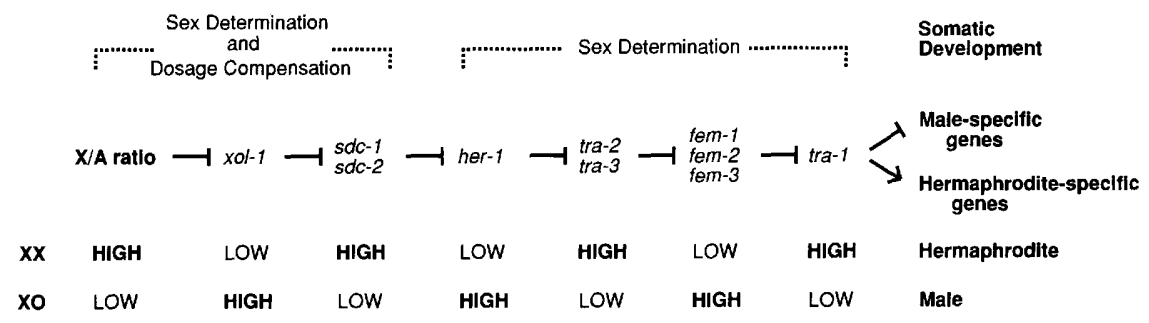

tion) (Hodgkin 1980), tra (transformer) (Hodgkin and Brenner 1977), and fem (feminization) (Kimble et al. 1984). Barred arrows indicate negative regulation (of either expression or function). Some of these genes also function in sex determination of the germ line, although additional genes are involved and some of the epistatic relationships differ (for review, see Hodgkin 1990). (Adapted from Villeneuve and Meyer 1990.)

function nonautonomously. A her-1(+) genotype for a given cell was shown to be neither necessary nor in some cases sufficient for adoption of the male fate in a mosaic $\mathrm{XO}$ animal, indicating that her $-1(+)$ cells must be able to masculinize her-1(-) cells and that her-1(-) cells, under some circumstances, can feminize her- $1(+)$ cells. These results showed that cell interactions play a role in C. elegans sex determination and implicated her-1 or a gene product under its control in intercellular signaling.

Here we report further characterization of the her-1 transcripts and their functions, indicating that this gene encodes a small protein that could act as a secreted ligand to determine male development in all tissues.

\section{Results}

\section{Structures of her-1 transcripts}

To confirm that the region identified by Trent et al. (1991) included all the elements required for her-1 activity, we demonstrated by germ-line transformation that an 8-kb genomic DNA fragment (Fig. 2A; pMPP14-22) can restore her-1 function to a mutant strain that lacks it. This strain, him-8(e1489); her-1(y101hv1), carries a small deletion eliminating most of the her-1 gene (Trent et al. 1991) and produces about $37 \%$ XO animals as a result of the him-8 mutation, which causes X-chromosome nondisjunction (Hodgkin et al. 1979). These animals develop as hermaphrodites because of the her-1 mutation; transformation with the rescuing fragment gave animals that had male morphology and exhibited male mating behavior. Sequencing of $\sim 7 \mathrm{~kb}$ of the transforming fragment (Fig. 3) identified four putative exons on the coding strand (determined by Trent et al. 1991), two in the region hybridizing to both transcripts and two in the region hybridizing only to the rarer $1.2 \mathrm{~kb}$ transcript. Screening of a cDNA library with appropriate genomic fragments yielded clones including sequences from the two putative $3^{\prime}$ exons ( 3 and 4 ) but none with sequences from the two putative $5^{\prime}$ exons ( 1 and 2$)$, present only in the rarer transcript. We obtained cDNAs spanning exons 1 and 2 by means of an anchored PCR technique (Frohmann et al. 1988; Loh et al. 1989) using a sequence from exon 3 as the downstream primer (see Materials and methods). To establish that exon 4 is cis- spliced to the first 3 exons to form the large transcript, we used PCR primers specific for exon 1 and exon 4 to amplify cDNA and sequenced the resulting product, confirming the structure shown in Figure 2 for the larger her-1 cDNA.

Sequencing of cDNAs (see Fig. 3, legend) demonstrated further that the $0.8-\mathrm{kb}$ transcript carries the SL1 transsplice leader present on the $5^{\prime}$ ends of about $10 \%$ of $C$. elegans mRNAs (Krause and Hirsh 1987; Bektesh et al. 1988). For the 1.2-kb transcript, the $5^{\prime}$ end of the cDNA sequence was the same as the genomic sequence, indicating no splice leader.

To confirm the exon/intron structures shown in Figures 2 and 3 and to define more precisely the $5^{\prime}$ ends of each transcript, we carried out mapping experiments using RNase protection (Melton et al. 1984), assaying probes representing appropriate regions of both DNA strands for protection by sequences in embryonic RNA. Representative assays are shown in Figure 4. Consistent with the earlier Northern blot experiments (Trent et al. 1991), total RNA from him-8 embryos gave strong protection of exon 3 (Fig. 4A) and exon 4 probes. Protection of exon 1 and 2 probes with total RNA was detectable only after long exposures; we used the poly(A)-containing fraction of RNA to obtain stronger signals (Fig. 4B). These experiments gave no evidence for other transcripts and confirmed the predicted splice sites. They revealed no additional exons in any of the predicted introns including intron 2, which at $3.3 \mathrm{~kb}$ is much larger than the average C. elegans intron (Emmons 1988). However, they showed that both the $5^{\prime}$ end of exon 1 (see Fig. 4B, legend) and the $3^{\prime}$ end of exon 4 can vary in length, suggesting that promoter elements controling the large transcript utilize multiple capping sites, and that the transcriptional termination machinery can choose between several poly $(\mathrm{A})$ addition sites.

\section{There are two her-1 promoters}

We have designated as P1 the presumed promoter for the larger transcript (Fig. 2). Although it appears to utilize multiple capping sites, all are upstream of the predicted ATG initiation codon at position 1652 of the genomic sequence (Fig. 3). We attempted to demonstrate P1 promoter activity directly by constructing and injecting the 
Figure 2. Physical map of the her-1 locus and constructs for germ-line transformation experiments. $(A)$ Top line shows a genomic restriction map (Trent et al. 1991). The 7-kb region sequenced extends rightward from the unique SacI site to a point just beyond the rightmost EcoRI site on the diagram. Boxes below the restriction map show the locations of the four her-1 exons; white boxes indicate untranslated regions of mRNA and black boxes indicate coding stretches. (ATG) Presumed points of translation initiation. ("P1" and "P2") Approximate locations of the two XO-specific her-1 promoters described in the text; arrows show the direction of transcription and indicate that $\mathrm{P} 2$ is more active than P1. The smallest genomic subclone tested in germline transformation rescue (pMPP14-22) is shown below the structure of the her-1 cDNAs. Promoter test plasmids consist of the indicated her-1 sequences fused to either a lacZ coding sequence (pMPL14, pWLG1) or a construct derived from the larger her-1 cDNA /see Materials and methods). Abbreviations for restriction enzyme recognition sites are: $\mathrm{H} 3$, HindIII; Sac, SacI; Pst, PstI; Bam, BamHI; RI, EcoRI. Individual exons of the her-1 gene are numbered; introns (not numbered in the figure) are counted from left to right starting with intron 1 between exons 1 and 2 . The small deficiency in her-1(y101hv1) strains, used in several experiments referred to in the text, removes sequences from a point to the left of the PstI site in the Pl region to a point approximately midway between the $\mathrm{H} 3$ and BamHI sites at the start of exon 4 (Trent et al. 1991). (B) Plasmids for ectopic expression experiments were constructed as described under Results and Materials and methods. pMPW12-1 (IV) and pMPX174 (VI) contain her-1 cDNA sequence corresponding to the larger transcript; pMPZ159 (V) and pMPZ162 (VII) contain cDNA sequence corresponding to the smaller transcript.

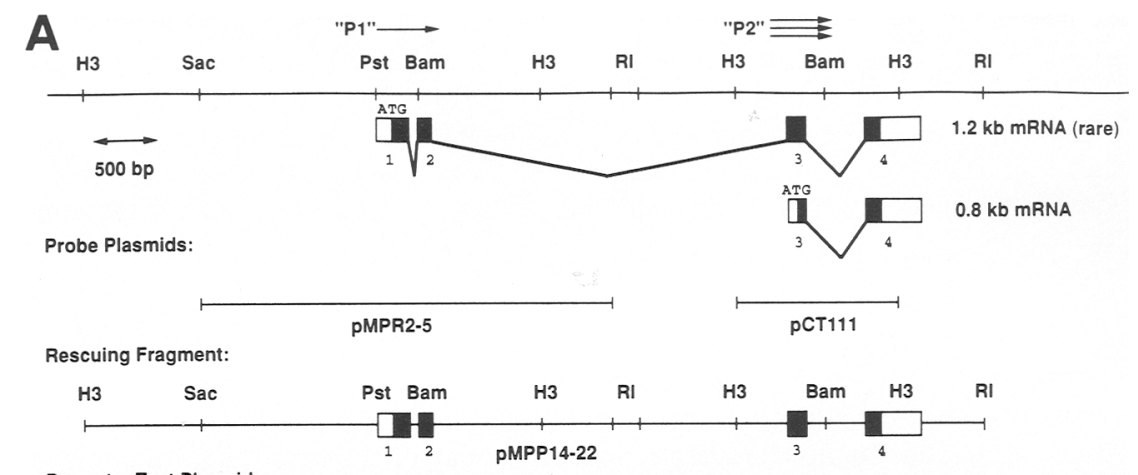

Promoter Test Plasmids:
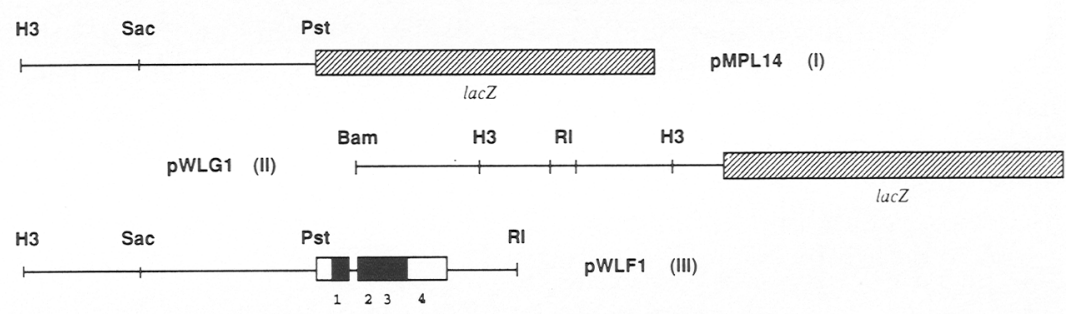

B

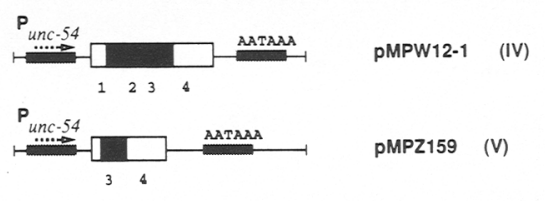

Expression plasmids:

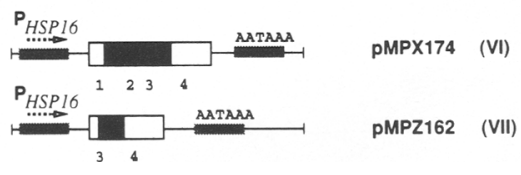

P1-lacZ fusion construct I (Fig. 2A, pMPL14) into him$8(e 1489)$ animals, but no $\beta$-galactosidase reporter activity was detected by histochemical staining with the chromogenic substrate X-gal (data not shown). Because her-1 mRNAs driven by P1 are normally present only at low steady-state levels (Trent et al. 1991), our inability to detect expression from $\mathrm{Pl}$ may simply reflect its very low activity, although we have not ruled out the possibility that promoter or enhancer elements could be missing from the construct.

The cDNA sequences indicated that the $5^{\prime}$ end of exon 3 can either be cis-spliced to exon 2, forming the $1.2-\mathrm{kb}$ mRNA, or trans-spliced to SL1, forming the $0.8-\mathrm{kb}$ mRNA. Examples of alternative cis- and trans-splicing for wild-type C. elegans mRNAs are rare, although mu- tant constructs engineered in vitro can be forced into this pattern (R. Conrad and T. Blumenthal, pers. comm.). Therefore, it seemed likely that the 0.8 -kb transcript might be under the control of a second promoter upstream of exon 3. RNase protection assays of the $5^{\prime}$ end of exon 3 (data not shown) revealed a weakly protected band about 35 nucleotides longer than the exon. Observation of this band, expected for a primary transcript that is subsequently trans-spliced, supports the existence of a second promoter, which we have designated $\mathrm{P} 2$, just upstream of the acceptor splice junction of exon 3. Similar detection of a primary transcript has been reported previously for other trans-spliced mRNAs (Graham et al. 1989 .

To obtain more direct evidence for P2 activity, we 


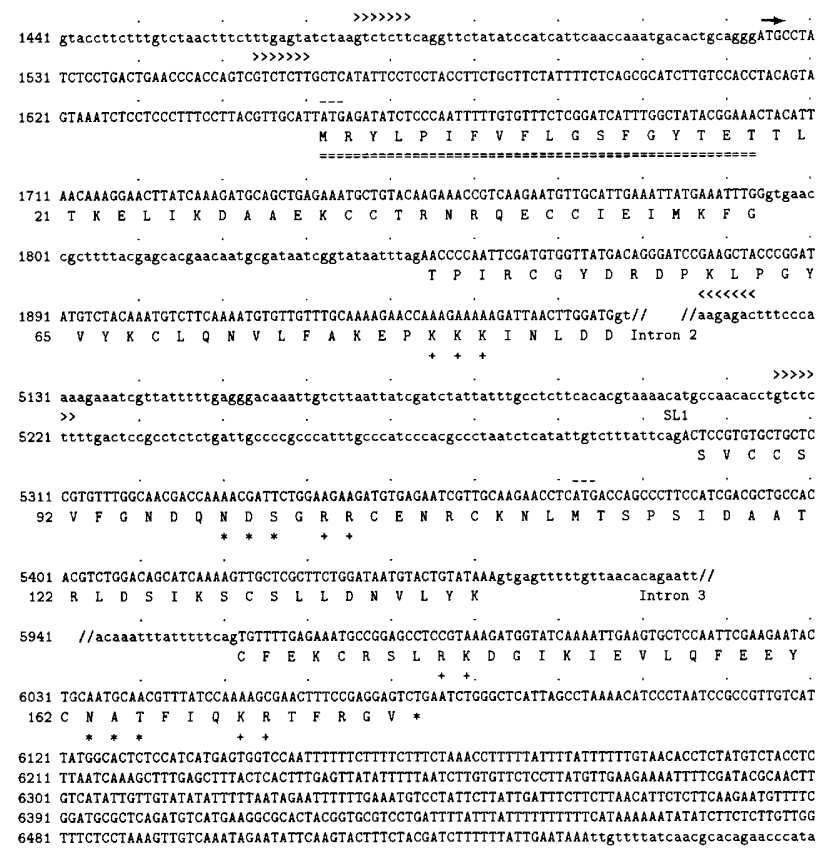

Figure 3. Sequences of genomic DNA and cDNAs at the her-1 locus, with amino acid sequences of predicted translation products. In the DNA sequence, which is numbered from an arbitrary point upstream of the start of transcription, regions present in cDNAs are in uppercase letters. The transcription start site thereby defined at position 1524 (arrow) is also consistent with RNase protection mapping (see text and Fig. 4). The predicted initiator methionine codons of the larger and smaller transcripts are overlined, and a repeated heptad in each promoter is marked with arrowheads. Only portions of the intron 2 and intron 3 sequences are shown. In cDNAs of the smaller transcript, the 22-nucleotide trans-spliced leader sequence SL1 (GGTTTAATTACCCAAGTTTGAG) is present at the $5^{\prime}$ end. The transcription start site for the $\mathrm{P} 2$ promoter maps approximately to position 5260 by RNase protection (see text). The predicted translation product of the larger transcript is shown below the DNA sequence using the standard one-letter amino acid abbreviations and numbered from the initiator methionine. The secretion signal sequence is double underlined, and two potential sites of $\mathrm{N}$-linked glycosylation $\left({ }^{\star \star \star}\right)$ as well as paired basic amino acid residues $(++)$ are indicated. Genomic DNA was sequenced on both strands as described in the text and in Materials and methods. cDNAs corresponding to the abundant 0.8-kb mRNA isolated from the phage library ( 2 clones) and by use of the RACE technique (2 clones) and cDNAs corresponding to the $5^{\prime}$ end of the rare $1.2-\mathrm{kb}$ mRNA isolated by use of the RACE technique ( 2 clones) were sequenced on one strand; any ambiguities were resolved by sequencing the complement. The cDNA sequence indicated by uppercase letters beginning at position 1524 is based on sequencing of the longer of the latter two clones. Although a transcript starting here would initiate with an AUG and a 4-codon ORF, this sequence is not required for her- 1 function, because the strongly masculinizing cDNA constructs such as IV (pMPW12-1, Fig. 2B) were made from the shorter cDNA clone, which begins at position 1584 .

made the reporter construct II (Fig. 2A, pWLG1), containing intron 2 fused to the $l a c Z$ gene, and coinjected it into him-8(e1489) hermaphrodites with a plasmid carrying the dominant Roller (Rol) allele rol-6(su1006) as a marker (Mello et al. 1991; see Materials and methods). From Rol progeny we obtained a transformed line carrying integrated copies of the construct and the marker DNA [linked to unc-37 on linkage group (LG)I]. About $35 \%$ of the embryos produced by this line showed strong $\mathrm{X}$-gal staining of most or all embryonic cells, beginning at about the 30-cell stage (Table 1; Fig. 5). The remaining embryos showed no staining. This result is consistent with staining of only $\mathrm{XO}$ embryos, which comprise about $37 \%$ of those produced in a him-8(e1489) population. Later stages of development showed staining of progressively fewer cells, which we have not yet analyzed in detail. We observed similar results when the construct was introduced into the her-1 deficiency strain him8(e1489); her-1(y101hv1), indicating that no her-1 activity is required for activation of $\mathrm{P} 2$.

To demonstrate that the P1 promoter can drive functional her-1 expression, we injected construct III (Fig. 2A, pWLF1), carrying her-1 5'- and 3'-flanking regions, the four exons, and intron 1, but lacking introns 2 and 3 including the $\mathrm{P} 2$ region, together with rol-6 marker plasmid as above into hermaphrodites of the her-1 deficiency strain him-8(e1489); her-1(y101hv1). Rol progeny were propagated to obtain a transformed line, which produced variably masculinized progeny. These progeny included fertile males, presumably of XO genotype since they produced complete male progeny when mated.

Both the P1 and P2 promoter regions contain two copies of the heptad repeat GTCTCTT as indicated in Figure 3 . In a search of sequences in the data bases, we found occurrences of this repeat near the start of several $C$. elegans genes.

\section{Both her-1 promoters are almost completely XO specific}

Trent et al. (1991) found by Northern blotting that N2 $\mathrm{XX}$ populations contained detectable levels (about $0.5 \%$ of XO levels) of the $0.8-\mathrm{kb}$ transcript but not the $1.2 \mathrm{-kb}$ transcript. These experiments could not establish whether the rare $1.2-\mathrm{kb}$ transcript was completely absent nor whether the presence of the $0.8-\mathrm{kb}$ transcript could be accounted for by the low level of XO males that arise by X chromosome nondisjunction in $\mathrm{N} 2 \mathrm{XX}$ populations. To resolve these questions, we used the more sensitive technique of RNase protection to compare levels of the two transcripts in embryos of a him-8(e1489) strain (about $37 \% \mathrm{XO}$ ), N2 ( $\sim 0.2 \% \mathrm{XO})$, and SP756 ( 0.02\% $\mathrm{XO}$, a hermaphrodite strain in which $\mathrm{X}$ nondisjunction is suppressed by the X-to-IV translocation mnT12 (Sigurdson et al. 1986). At optimal exposure levels for the him-8 RNA signal (Fig. 4A, lane 5), we observed no signal with RNA from embryos of either N2 or the mnT12 strain (lanes 3,4), but longer exposures showed that these RNAs gave similar low levels of protection of the exon-3 probe. Even using isolated poly(A)-containing mRNA fractions, however, we could not detect protection of an exon-1,2 probe with N2 or mnT12 RNA. Therefore, XX embryos contain no $1.2-\mathrm{kb}$ transcript detectable by this 
Figure 4. Results of representative RNase protection experiments. $(A)$ Autoradiograph of a denaturing gel showing protection of her-1 exon 3 probe fragments (square bracket) and control act-1 probe (arrowhead) by various total RNA preparations. Antisense RNA probes for her-1 (spanning exon 3, positions 4821-5603 in Fig. 3) and act-1 (Krause et al. 1989) were hybridized to total $C$. elegans RNA and digested with RNase as described in Materials and methods (in this experiment $\sim 2 \times 10^{5}$ cpm of each probe was hybridized to $120-160 \mu \mathrm{g}$ of RNA). In most experiments, protected fragments were seen as sets of bands varying in length by $2-15$ bases, generally attributed to breathing at the ends of probe-mRNA duplexes causing variable protection of the ends. For example, the protected exon 3 fragments in lane 5 range from 150-165 bases in length. (Lane 1) her-1 probe, undigested; (lane 2) yeast tRNA carrier hybridized to the her-1 and act-1 probes; (lane 3$) \operatorname{mnT12}(I V ; X)$ RNA hybridized to the her-1 and act-1 probes; (lane 4) N2 RNA hybridized to the her-1 and act-1 probes; (lane 5) him-8 (e1489) RNA hybridized to the her-1 and act-1 probes; (lane 6) size markers derived from an end-labeled Sau3A digest of pBR322; (lane 7) her-1(y101gf) RNA hybridized to the act-1 probe only; (lane 8) act-1 probe, undigested. The sizes of the molecular weight markers in base pairs are indicated to the right of the gel. $\langle B|$ Autoradiograph from a similar experiment showing protection of a her-1 exon 1 fragment (arrow) by various RNA preparations. Antisense RNA probes for her-1 (spanning part of exon 1 and all of exon 2, positions 1658-1969 in Fig. 3) and act-1 were used as in $A$, with the same size markers. Lanes are as in $A$, except that the $C$. elegans RNAs in lanes $3,4,5$, and 7 were fractions selected to contain poly(A). A 113-nucleotide protected exon 2 fragment also seen in lane 5 is not included in the reproduced portion of the autoradiograph. The her-1 probe used in this experiment does not include the transcriptional start site and the $5^{\prime}$-UTR of the large transcript. In similar experiments (not shown) using probes that extend further 5 ' we observed four sets of male-specific protected exon 1 bands indicating multiple capping sites; the largest was the size expected from the transcriptional start site shown in Fig. 3.

assay, but they do contain low levels of the 0.8 - $\mathrm{kb}$ transcript, which cannot be attributed to spontaneously arising XO males in the population.

Results obtained with the P2-lacZ reporter construct II described above were consistent with these observations. Crossing the integrated construct into an N2 background without the him- 8 mutation yielded an $\mathrm{XX}$ strain that showed little or no embryonic staining with X-gal (Table 1). Crossing this strain with males to produce XO offspring again produced staining embryos, indicating that the construct was still active.

The larger her-1 transcript is predicted to encode a polypeptide with a secretion signal sequence

The 1.2-kb transcript contains an open reading frame (ORF) of $525 \mathrm{bp}$, beginning at an AUG codon 128 nucleotides from the $5^{\prime}$-most transcriptional start site (see Figs. 3 and 4B, legends) and predicted to encode a 175residue polypeptide with an $M_{r}$ of $\sim 20 \mathrm{kD}$ (Fig. 3). This ORF is spliced in-frame across all three exon-exon splice sites, and includes the ORF found in the smaller transcript (see below). The predicted polypeptide includes at

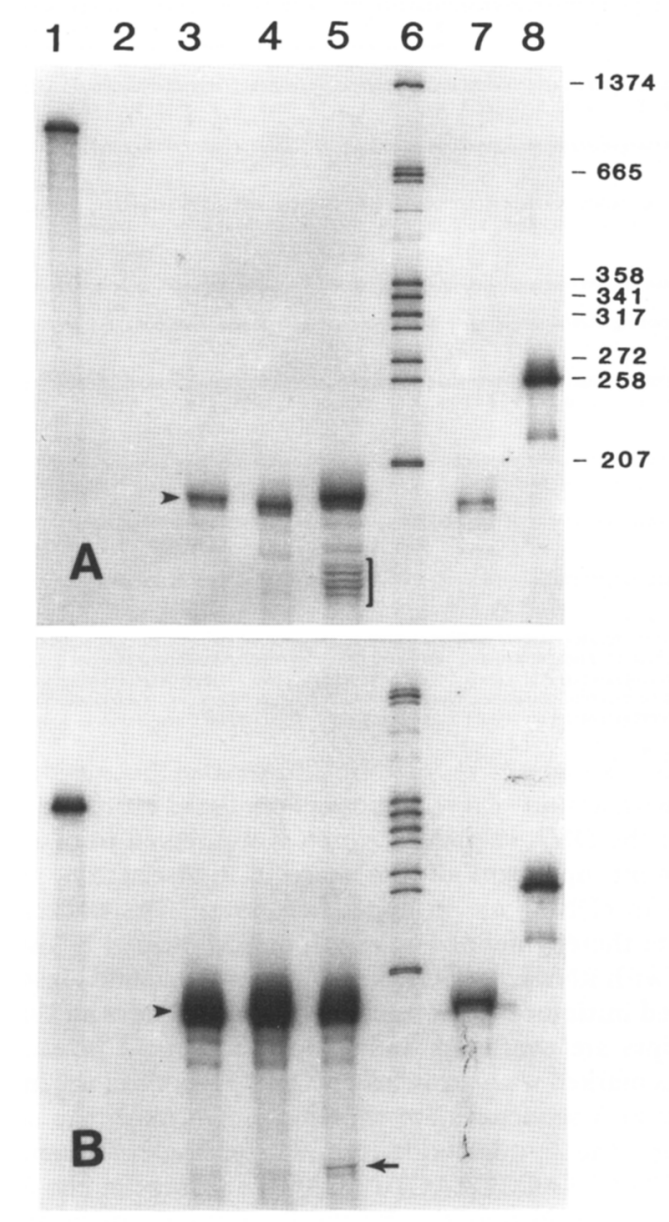

its amino-terminal end an apparent signal sequence (von Heijne 1986) for secretion into the endoplasmic reticulum (i.e., a basic residue next to the initiator methionine, followed by a stretch of 14 largely apolar residues, terminating in another charged residue, glutamate). Otherwise the polypeptide shows no significant sequence similarities to any proteins in the current data bases (see Materials and methods). It does include, however, two potential sites (residues 98 and 163) for post-translational amino-linked glycosylation (Kornfeld and Kornfeld 1985), as well as four pairs of basic residues that could be sites for post-translational proteolytic processing (Douglass et al. 1984). Because there are no additional membrane-spanning domains, the polypeptide or a processed form of it could be secreted at the cell surface.

The $0.8-\mathrm{kb}$ transcript includes a $220-\mathrm{bp}$ ORF that begins at the point of trans-splicing (Fig. 3) and corresponds to exons 3 and 4 of the larger transcript. At position 77 of the smaller transcript (5372 in the genomic sequence) is an AUG codon. Initiation of translation at this site would result in a polypeptide of about $10 \mathrm{kD}$, corresponding to the carboxy-terminal 64 amino acids of the larger polypeptide. Curiously, the first AUG in this tran- 
Table 1. Expression of an integrated P2-lacZ fusion construct in $X X$ and $X O$ embryos

\begin{tabular}{|c|c|}
\hline $\begin{array}{l}\text { Genotype of animals } \\
\text { carrying construct }\end{array}$ & Staining/total embryos \\
\hline 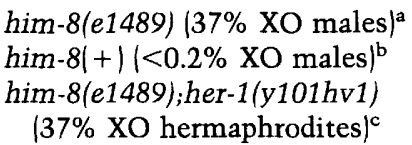 & $\begin{array}{r}350 / 1003 \\
2 / 1071 \\
271 / 1043\end{array}$ \\
\hline
\end{tabular}

${ }^{a} \mathrm{~A}$ him-8(e1489) strain carrying chromosomally integrated copies of the P2-lacZ fusion construct III (Fig. 2A, pWLG1) were obtained by germ-line transformation and irradiation of a stably transformed line as described in Materials and methods.

'To obtain a strain carrying the construct without the him-8 mutation, hermaphrodites of the above strain were crossed to N2 males and the desired line was propagated from an F2 hermaphrodite that exhibited the Rol phenotype and produced no male offspring. Retention of the active P2-lacZ fusion construct was verified by mating with N2 males and observing a high proportion of embryos that stained with X-gal.

'This strain was obtained by (1) crossing N2 males with hermaphrodites of the strain described in footnote a, (2) crossing $\mathrm{F}_{1}$ males to him-8(e1489); her-1(y101hv1) hermaphrodites, (3) picking Rol $F_{1}$ hermaphrodites from the second cross that produced $\mathrm{F}_{2}$ male progeny, $(4)$ and picking their Rol hermaphrodite siblings to individual plates and retaining a Rol clone that no longer produced males, indicating homozygosity of the her-1 mutation. Because $\sim 37 \%$ of him-8(e1489)her-1(y101hv1) hermaphrodites are $\mathrm{XO}$, such strains produce inviable nullo- $\mathrm{X}$ embryos, which could account for the lower than expected fraction of total embryos stained. When apparently healthy embryos of $\sim 100$ cells (identified by DAPI fluorescence) were counted, 39/ 100 were found to stain with X-gal.

script is further upstream $(5347$ in the genomic sequence), immediately followed by a UGA terminator. Because most eukaryotic mRNAs seem to be scanned from their 5' ends for initiation codons (Kozak 1983), a scanning ribosome would have to reinitiate at the second AUG if this transcript is translated conventionally (Peabody and Berg 1986).

\section{Expression of the larger her-1 transcript driven by a body-wall muscle myosin promoter masculinizes all dimorphic tissues}

To further characterize masculinizing effects of the two predicted her-1 products, we asked whether expression of either of the two her-1 transcripts in body-wall muscle could affect sex determination of other tissues. Each of the two cDNAs was subcloned into the expression plasmid pPD30.38 (P. Okkema, S. White-Harrison, V. Plunger, A. Aryana, and A. Fire, in prep.), containing an enhancer, promoter, and poly(A) addition signal from the unc-54 gene, which encodes the major body-wall muscle myosin protein (Epstein et al. 1974). The unc-54 protein and its mRNA are expressed in body muscle cells, most of which are not sexually dimorphic (Sulston et al. 1983). When worms are transformed with a lacZ fusion construct driven by this unc-54 enhancer-promoter combi- nation, $\beta$-galactosidase activity is detected only in these same muscle cells (Fire et al. 1990; P. Okkema, S. WhiteHarrison, V. Plunger, A. Aryana, and A. Fire, in prep.).

We coinjected construct IV (Fig. 2B, pMPW12-1), carrying the larger her-1 cDNA, with marker rol-6 DNA as above into $\mathrm{N} 2$ hermaphrodites, and screened their progeny for Rol transformants. Of the Rol animals from this experiment, $59 \%$ showed masculinization (Table 2), ranging from hermaphrodites with slightly truncated tails or intersexual gonads to animals of male size and shape, with male gonads containing only sperm and distinctly masculinized tails (sensory rays, acellular fan, crumpled spicules). One such animal is shown in Figure 6D. The strongly transformed animals did not produce vitellogenin, indicating that the intestine was also masculinized. When we injected the same construct (IV) into hermaphrodites of the her-1 deletion strain him8(e1489); her-1(y101 hv1), transformed animals produced apparently complete male progeny (Fig. 6C).

These results indicate that the larger her-1 transcript encodes biologically active her-1 product. Because the unc-54 promoter-enhancer is reported to be tissue-specific (Fire et al. 1990), they are also consistent with the
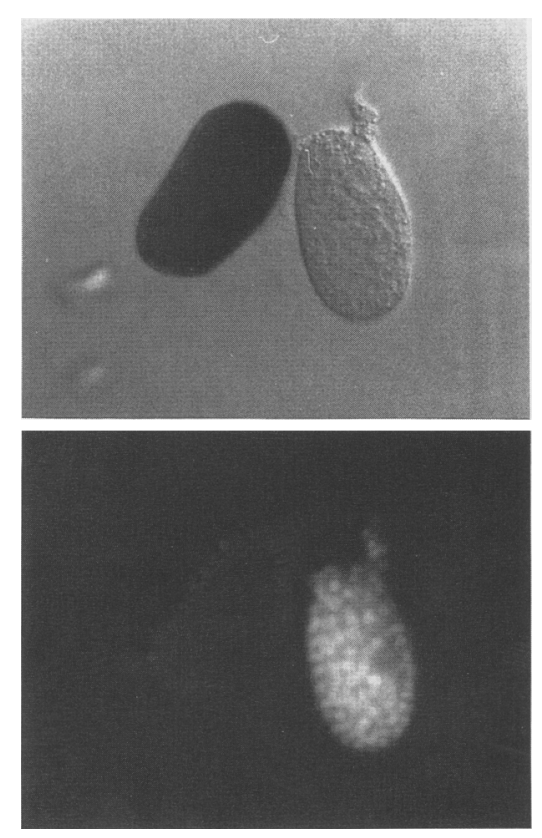

Figure 5. Expression of an integrated her-1 P2-lacZ fusion construct in embryos of a him-8(e1489) hermaphrodite. A line carrying the integrated construct was obtained as described in Materials and methods after germ-line transformation of him8(e1489) with pWLGl (see Fig. 2). About $35 \%$ of embryos (presumed XOs) from this line show expression (Table 1). Animals were fixed, stained with X-gal and DAPI (see Materials and methods) and viewed under Nomarski (upper panel) or epifluorescence (lower panel) optics. DAPI staining in the lower panel indicates that the two embryos shown are at approximately the same stage (100-200 nuclei), although epifluorescence in the presumed XO embryo on the left is obscured by the heavy X-gal staining. 
Table 2. Dominant sexual transformations in transgenic N2 hermaphrodites

\begin{tabular}{|c|c|c|c|c|c|c|}
\hline \multirow[b]{2}{*}{ Plasmids } & \multicolumn{6}{|c|}{ Number of animals with transformed tissues } \\
\hline & $\begin{array}{l}\text { masculinized } \\
\text { tail }^{\mathrm{a}} \\
\text { (AB-derived) }\end{array}$ & $\begin{array}{l}\text { masculinized } \\
\text { vulva }{ }^{\mathrm{b}} \\
\text { (AB-derived) }\end{array}$ & $\begin{array}{l}\text { masculinized } \\
\text { intestine }^{c} \\
\text { (E-derived) }\end{array}$ & $\begin{array}{l}\text { masculinized } \\
\text { gonad } \\
\text { (MS-derived) }\end{array}$ & $\begin{array}{l}\text { masculinized } \\
\text { sex muscles } \\
\text { (MS-derived) }\end{array}$ & $\begin{array}{l}\text { masculinized } \\
\text { germ line }^{d} \\
\left(\mathbf{P}_{4} \text {-derived }\right)\end{array}$ \\
\hline \multicolumn{7}{|l|}{ unc-54-her-1 } \\
\hline (pMPW12-1) & $19 / 44$ & $18 / 44$ & $25 / 44$ & $25 / 44$ & $4 / 27$ & $13 / 44$ \\
\hline \multicolumn{7}{|l|}{ HSP16-her-1 } \\
\hline (pMPX174) & $22 / 22$ & $9 / 21$ & $11 / 22$ & $15 / 21$ & $3 / 4$ & $14 / 20$ \\
\hline
\end{tabular}

${ }^{a}$ Weakly transformed animals were missing the tail spike, whereas strongly transformed animals had sensory rays, acellular fan, mating hook, and spicule material.

bSecific cells were not lineaged; vulval induction was scored by the presence of a normal vulva or a mid-ventral hernia.

'Sex of the intestine was assessed either by the accumulation of pseudocoelomic yolk protein visible by Nomarski microscopy or by the presence of developing embryos in utero (assuming that yolk protein is necessary for embryogenesis; Hunter and Wood 1990), or both.

${ }^{\mathrm{d}}$ Overproduction of sperm.

suggestion that her-1 product or some other molecule under its control is secreted and able to act on other tissues. However, because only low levels of her-1 product may be required for activity, based on the apparent weakness of the P1 promoter, we cannot rule out the possibility of masculinization attributable to low-level ectopic expression of the construct in nonmuscle cells.

\section{Expression of the smaller her-1 transcript may be unimportant for male development}

Construct V (Fig. 2B, pMPZ159), carrying the smaller her-1 cDNA under control of the unc-54 promoter-enhancer appeared to have no masculinizing effect in ex-

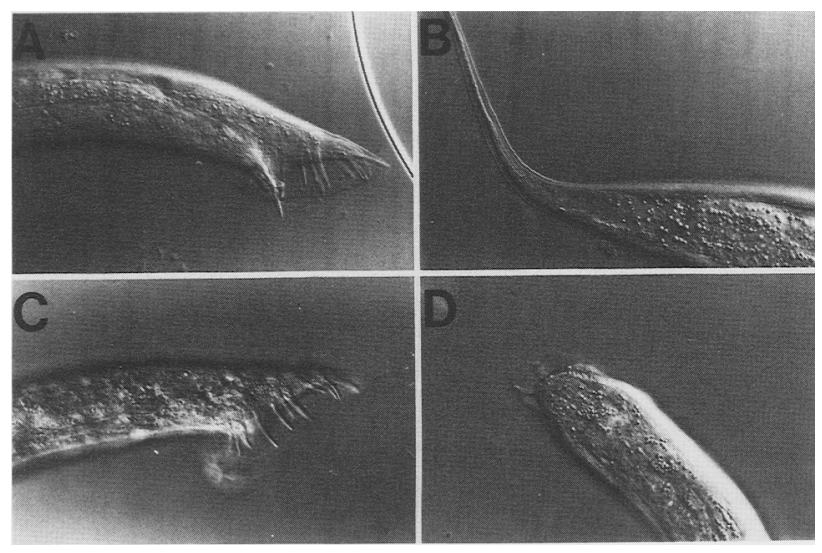

Figure 6. Nomarski photographs showing masculinization of animals expressing the $1.2-\mathrm{kb}$ her-1 transcript under the control of a body-wall-muscle-specific promoter. $(A$ and $B)$ Normal male and hermaphrodite (N2) tails, respectively, for comparison (lateral views). (C) F1 offspring (presumably XO) of a him8(e1489)her-1(y101hv1) animal transformed with pMPW12-1 (Fig. 2, construct IV), showing apparently complete masculinization of the tail (lateral view). (D) XX F1 offspring of an N2 animal transformed with pMPW12-1 and rol-6 marker, showing partial masculinization of the tail (ventral view). pression experiments similar to those above. In this and the following experiments, presence of the construct in the transformed animals was verified by PCR as described in Materials and methods. We would not expect the resulting polypeptide to be secreted, and because body wall muscle is not sexually dimorphic, we would not be able to score cell-autonomous masculinization in these cells. The unc-54 promoter is active in the dimorphic sex muscles that arise during larval development (Hodgkin 1988), but expression of her-1 in these cells could be too late to affect their sexual fates. As a more general test for function of the smaller transcript, we made the constructs VI and VII (Fig. 2B, pMPX174 and pMPZ162) containing the her-1 cDNAs fused to a $C$. elegans HSP16 heat shock promoter (Stringham et al. 1992; D. Dixon, S. Harrison, and A. Fire, in prep.). Subjecting transformed lines made with these constructs to a heat-shock during embryogenesis (see Materials and methods) confirmed the above results: We observed strong masculinization with the larger cDNA construct pMPX174 (Table 2) but no masculinization with the smaller cDNA construct.

Expression of the smaller transcript may not be necessary for male development. As described above, we observed complete masculinization of XO animals from the her-1 deficiency strain him-8(e1489);her-1(y101hv1) after transformation with construct II (Fig. 2A, pWLF1), which lacks the P2 promoter region and the splice acceptor sequence adjacent to exon 3 in the genomic sequence. This result suggests that at least when this her-1 construct is present on an extrachromosomal array, expression from the $\mathrm{P} 1$ promoter is sufficient to direct normal male development.

\section{Masculinization by the larger her-1 polypeptide requires presence of a signal sequence}

To ask whether the putative her-1 signal sequence is required for masculinizing activity, we modified the masculinizing cDNA construct I (pMPW12-1), which en- 
codes the complete her-1 large polypeptide (Fig. 7, top), to a truncated derivative (pMPE21-2), which encodes the same polypeptide without the signal sequence. In transformation experiments similar to those described above, this construct showed no detectable masculinizing activity of either XX or XO her-1(-) animals. Therefore, the amino-terminal sequence of the normal translation product is important for masculinizing activity, either as a signal sequence or fulfilling some other necessary function. To distinguish between these alternatives, we used a plasmid constructed to substitute a heterologous secretion signal plus several more amino acids for the normal amino terminus of the her-1 product. The plasmid (pPD52.81; A. Fire, unpubl.) was designed to encode a synthetic sequence with features similar to known eukaryotic signal sequences and to place the resulting cDNA under the control of the unc-54 promoter as above. An appropriate fragment of her-1 cDNA was cloned into this plasmid to give an in-frame fusion to the her-1 polypeptide sequence (Fig. 7, pMPD24-1), starting at residue 16. The amino-terminal sequence of the resulting polypeptide bears little resemblance to the her-1 signal sequence, which is completely missing. In germline transformation experiments this plasmid strongly masculinized both $\mathrm{XX}$ and $\mathrm{XO}$ animals of the her- 1 deficiency strain him-8(e1489);her-1(y101hv1). These results suggest that the normal amino terminus of the her-1 product is required as a signal sequence for masculinizing activity.
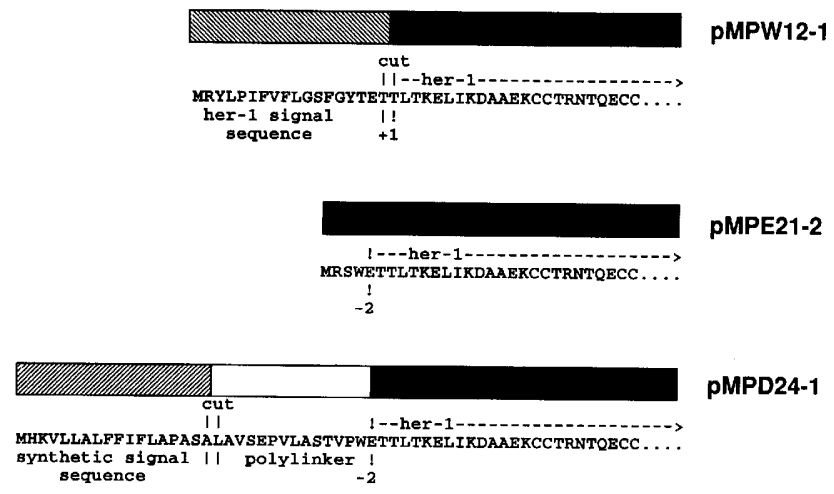

Figure 7. Evidence that her-1 function requires a signal sequence. Shown are amino-terminal polypeptide sequences encoded by the full-length larger her-1 cDNA construct IV (Fig. 2) and constructs modified to test the requirement for a signal sequence in her-1-mediated masculinization. The upper diagram shows the probable cleavage site (von Heijne 1986) for removal of the normal presumed signal sequence, which would leave an amino-terminal $\mathrm{Thr}$ residue (!). The amino terminus of the second polypeptide, with no signal sequence, would be expected to remain as shown with 6 additional residues preceding the normal amino-terminal Thr. The third polypeptide has a substituted synthetic signal sequence and an additional aminoterminal sequence that would be expected to remain after cleavage. The exclamation point (!) in the second and third diagrams indicates the leftmost extent of normal her- 1 sequence in the predicted polypeptides. (See text for additional description of the plasmids.)

\section{Discussion \\ her-1 encodes a small protein that may require secretion for its activity}

We have shown that the two previously described transcripts (Trent et al. 1991) of the masculinizing gene her-1 are produced from separate promoters, designated $\mathrm{P} 1$ and $\mathrm{P} 2$, both active in XO animals and essentially inactive in $\mathrm{XX}$ animals. The larger transcript, from $\mathrm{P} 1$, is predicted to encode a polypeptide with an apparent amino-terminal signal sequence and potential glycosylation and cleavage sites, suggesting that it could be post-translationally processed and secreted. We have shown that expression of the full-length her-1 cDNA from the large transcript under the control of a myosin heavy-chain promoter reported to be tissue specific causes masculinization of all dimorphic tissues in XX animals. We have shown further that this activity is dependent on the presence of the her-1 signal sequence or a substitute synthetic signal sequence in the encoded polypeptide. These results suggest that the larger product of the her-1 gene may act in a secreted form to dictate male development.

The smaller transcript, predicted to encode a polypeptide corresponding to the 64 carboxy-terminal amino acids of the larger polypeptide, does not appear to have masculinizing activity. Moreover, expression of the larger cDNA from constructs that lack P2 in the absence of an endogenous her-1 gene results in development of fertile XO males, suggesting that transcription from $P 1$ is sufficient for complete male development. Although these results do not rule out involvement of the smaller transcript in normal sex determination, they suggest that its functions are not essential for male development.

\section{Is transmembrane signaling involved in $\mathrm{C}$. elegans sex determination?}

The molecular results reported here provide a potential explanation for the conclusion from genetic mosaic analysis by Hunter and Wood (1992), described in the introductory section, that the her-1 gene could act nonautonomously to determine male sexual development. On the basis of previous genetic evidence, the most likely target of her-1 action is the tra-2 gene or its products (see Fig. 1). Okkema and Kimble (1991) have cloned tra-2 and shown that, in adults, the steady-state levels of the major transcript are 15-fold lower in males than in hermaphrodites, although it is expressed in both sexes. More recently, Kuwabara et al. (1992) have shown that the major somatic product of tra-2 predicted from sequencing is a large protein with an apparent signal sequence and several other hydrophobic domains capable of spanning the plasma membrane. As previously pointed out (Hunter and Wood 1992; Kuwabara et al. 1992; Kuwabara and Kimble 1992), these results suggest that the tra-2 product could be the cell-surface receptor for a her-1-encoded ligand.

The earlier genetic evidence (for review, see Hodgkin 1987) indicated that in the absence of her-1 activity (the 
normal situation in $\mathrm{XX}$ animals), the tra-2 gene product acts with the help of the tra-3 product to inhibit the activity or expression of one or more of the masculinizing fem gene products, thereby allowing tra-1 action to direct hermaphrodite development (see Fig. 1). Two of the three fem gene products, fem-1 (Spence et al. 1990) and fem-3 (Ahringer et al. 1992) have been cloned and sequenced; both are predicted to encode hydrophilic presumably cytoplasmic proteins that show no sequence similarity to known proteins except for six repeats of a $c d c-10 / S W I 6 / a n k y r i n$ motif in the fem-1 product. The tra-1 gene acts cell autonomously (Hunter and Wood 1990 ) and is predicted to encode two proteins with zincfinger domains similar to those of the human GLI and Drosophila cubitus interruptus Dominant genes (Zarkower and Hodgkin 1992).

Secreted her-1 protein could bind to the extracellular domain of a tra-2-encoded receptor, inhibiting the activity of its cytoplasmic domain and thereby allowing the fem gene products to inhibit tra-1 to enable male development. Alternative mechanisms can also be imagined, however; for example, her-1 product could interact with some other cell-surface receptor, which would relay the signal to the tra-2 protein. The gene for such a receptor could have escaped identification in the previous extensive genetic screens for sex transformer mutants if it were redundant in function with another gene product or if it had other functions essential for viability. Direct inhibition of tra-2 function by binding of her-1 product is merely the simplest model pending further investigation.

Neither the her-1 nor the tra-2 (Kuwabara et al. 1992) predicted translation products shows significant sequence similarity to any known proteins, with the possible exception of slight similarity between the tra-2 product and the product of the Drosophila segment-polarity gene patched (ptc). The her-1 product, however, does not show significant similarity to the product of the Drosophila hedgehog (hh) gene (Lee et al. 1992), postulated (Ingham et al. 1991) to encode a ligand for the putative ptc-encoded receptor (Hooper and Scott 1989; Nakano et al. 1989).

The interaction proposed in the simple model above would be somewhat unusual in that the her-1 product inhibits tra-2 function. Although ligand-receptor interactions generally activate receptor functions, a few cases of naturally occuring protein ligands that inhibit their cognate receptors have been reported or postulated. Two examples are $p p 63$, the inhibitor of the insulin receptor tyrosine kinase (Auberger et al. 1989) and the interleukin-1 receptor antagonist (Hannum et al. 1990). Another could be Mullerian Inhibiting Substance (MIS), which may act in mammalian male gonad development by binding to and inhibiting an EGF-tyrosine kinase receptor (Cigarroa et al. 1989).

A priori, it might not have been expected that transmembrane signaling should be required to determine cellular sexual identities in C. elegans, a simple animal with few cells, many of whose developmental fates are determined cell autonomously (Sulston et al. 1983). One possible explanation is that intercellular signalling by the her-1 product evolved to provide an error correcting mechanism for cells that aberrantly adopt a female fate in an XO animal. Such an error could result from misreading of the $\mathrm{X} / \mathrm{A}$ primary signal, the nature of which is not yet understood. An ambiguous $\mathrm{X} / \mathrm{A}$ reading could be compounded by the recent suggestion that active tra-2 product, when uninhibited by her-1 action, may indirectly up-regulate its own synthesis (Okkema and Kimble 1991), which would further push an aberrant cell in an XO animal toward a female fate. In Drosophila, misreading of $\mathrm{X} / \mathrm{A}$ is presumably corrected by the $S \mathrm{X} l$ gene, which dictates both sex determination and dosage compensation after its activity level is set to the male or female mode by the X/A ratio (Cline 1984). Because inappropriate dosage compensation is a cell-lethal condition, cells that assess X/A aberrantly and set $S x l$ incorrectly die and do not contribute to the imago. In a fixed lineage animal like $C$. elegans, such a cell death mechanism could not be used, but the paracrine effects of a her-1-encoded ligand could serve the same purpose. If an occasional cell in an XO animal aberrantly assesses its $\mathrm{X} / \mathrm{A}$ ratio such that its her-1 gene is not expressed, secretion of the ligand by neighboring cells would reset the aberrant cell's sex determination pathway to the male mode, thereby ensuring a complete set of the male-specific structures required for mating. This proposal might require that there also be some nonautonomous mechanism for correcting the dosage compensation error that would result from misreading the $\mathrm{X} / \mathrm{A}$ ratio, also possibly a cell-lethal condition in C. elegans /Villeneuve and Meyer 1990).

Alternatively, cell signaling in present-day C. elegans sex determination may have no adaptive value. In some species of plant parasitic nematodes, sex is determined not by genotype but rather by conditions in the infested plant (Triantaphyllou 1973), requiring a mechanism for transduction of signals from the environment. A transmembrane signaling step in C. elegans could be an evolutionary holdover from an ancestor with environmentally determined sex.

Cell interactions are implicated in a growing number of developmental events in C. elegans, including specification of embryonic (Priess and Thomson 1987; Schnabel 1991; Wood 1991) and post-embryonic lineages (e.g. Seydoux and Greenwald 1989; Waring and Kenyon 1990) and induction of vulval development in hermaphrodites (for review, see Horvitz and Sternberg 1991). Our results support a role for cell-cell signaling in C. elegans sex determination as well and suggest a mechanism by which it may occur.

\section{Materials and methods \\ C. elegans strains, culture, and general methods}

Techniques for growing, handling, and microscopy of C. elegans have been described previously (Brenner 1974; Sulston and Hodgkin 1988; Trent et al. 1988, 1991). All strains were derived from C. elegans var. Bristol (N2). The following mutations used in this study were obtained from our collection or from the 
Caenorhabditis Genetics Center: Linkage group (LG) II, rol6(su1006); LGIV, him-8(e1489); LGV, her-1(y101hv1), (e1520). The translocation mnT12 is a fusion of chromosomes IV and X (Sigurdson et al. 1986).

\section{$D N A$ and RNA isolation and characterization}

Total RNA was isolated from embryos using guanidinium isothiocyanate (Trent et al. 1991). Poly(A) ${ }^{+}$RNA was isolated using oligo(dT) cellulose (Sambrook et al. 1989; Trent et al. 1991). Standard techniques were used to isolate restriction fragments for radiolabeling or subcloning (Sambrook et al. 1989). DNA sequencing was performed using chain terminators (Sanger et al. 1977) and modified T7 DNA polymerase (Sequenase 2.0, U.S. Biochemicals). Nested deletions for sequencing large sections of genomic DNA were generated in vivo using a Tn9-GalE system (Ahmed 1984a,b; Gold BioTechnology, St. Louis, MO).

\section{Isolation of her-1 cDNA clones}

cDNA clones corresponding to the $0.8-\mathrm{kb}$ her- 1 transcript were obtained by exhaustively screening a him $-8(\sim 37 \%$ XO) embryonic $\lambda g t 11$ cDNA library (Schauer and Wood 1990) with cloned genomic DNA fragments including exons 3 and 4 (pCT111), which had been ${ }^{32} \mathrm{P}$-labeled by use of random primers (Feinberg and Vogelstein 1983; Benton and Davis 1977).

cDNA clones corresponding to the $1.2-\mathrm{kb}$ transcript were obtained using a modified RACE protocol (Frohmann et al. 1988; Loh et al. 1989). A primer complementary to the 5 '-end of exon $3, \mathrm{JH} 3$, was used to prime first-strand cDNA synthesis (see below for list of primer sequences). After tailing with terminal deoxynucleotidyl transferase and dATP, an empirically determined amount of this cDNA was used as template for PCR. The upstream primer was a $9: 1$ mixture of MPAN-1 and $X b a \mathrm{I}$ primer-adaptor, and the downstream primer, $\mathrm{JH} 2$, was a segment overlapping the primer used for cDNA synthesis. Amplified fragments were rendered blunt-ended with Escherichia coli DNA polymerase I (Klenow fragment). The reaction mixture was extracted once with an equal volume of phenol- $\mathrm{CHCl}_{3}$, precipitated with ethanol, and fractionated on a $1.2-\mathrm{ml}$ spin column of Sephadex G-50. The resulting duplex cDNA was either (1) ligated to an excess of phophorylated linkers and digested with appropriate restriction enzymes, or (2) digested without adding linkers for subcloning and DNA sequencing.

PCR Primers: $5^{\prime}$ to $3^{\prime}$ are as follows: $X b a I$ primer/adaptor: GTCGACTCTAGATTTTTTTTTTTTTTT; MPAN1: GGCTCGAGGTCGACTCTAGATT; JH3: CACATCTTCTTCCAGAATCG; JH2: GAATCGTTTTGGTCGTTGCC; MP3: GAACTTATCAAAGATGCAGCTG; MP6: TTCAGACTCCTCGGAAAGTTCG; MP10: GGACCCAAAGGTATGTTTCG.

\section{Transcript mapping by RNase protection}

RNase protection assays were performed using standard procedures (Melton et al. 1984; Sambrook et al. 1989). Genomic fragments spanning an $8-\mathrm{kb}$ region and including all the predicted exons were subcloned into suitable vectors containing phage T7 and $\mathrm{T} 3$ promoters. These were used for in vitro transcription with phage T3 or T7 RNA polymerase and ${ }^{32} \mathrm{P}-\alpha$-UTP to generate asymmetric RNA probes labeled to high specific activity. To allow comparisons of different assays and estimation of transcript levels, amounts of mRNA in the hybridization reactions were normalized by comparing the signal of the fragments protected by her-1 probes to those protected by a probe specific for the C. elegans actin gene act-1 (Fig. 4).

\section{Plasmid constructions}

pMPL14, $p W L G 1$ : The lacZ fusion constructs, which carry a nuclear localization sequence in addition to the $\operatorname{lac} Z$ coding sequence, were derived from plasmids described by Fire et al. (1990).

pWLF1: To obtain a full-length cDNA corresponding to the larger her-1 transcript, two primers, MP3 in exon 1 and MP6 in exon 4, were used to amplify the correct fragment from him- 8 cDNA. After digestion with the appropriate enzymes, the fragment was fused to flanking cDNA segments in a tripartite ligation to generate pMPP13-1. pMPP13-1 was used as a source of full-length 1.2-kb cDNA for construction of pWLF1 and the plasmids listed below.

$p M P W, p M P X$, and $p M P Z$ plasmids: The ectopic expression vectors (Fig. 2B) into which her-1 cDNA fragments were inserted for muscle-specific expression or expression in response to heat shock contain the indicated promoters (see Results) and the 3 '-untranslated region from the unc-54 gene, flanking insertion sites for coding sequences (D. Dixon, S. White-Harrison, and A. Fire, in prep.). The plasmid used for expression of a her-1 polypeptide with substituted signal sequence (pPD52.81; A. Fire, unpubl.) contained the unc-54 promoter and enhancer region, the signal sequence cassette, and a polylinker cloning site.

\section{DNA-mediated transformation of C. elegans and histochemical staining of transgenic animals}

Transgenic worms were generated essentially as described by Mello et al. (1991). Plasmid DNAs at a concentration of 100-200 $\mu \mathrm{g} / \mathrm{ml}$ were mixed with Fire's injection buffer (minus the Lucifer Yellow) (Fire 1986) and injected into the distal syncytial gonads of young adult hermaphrodites. The dominant marker rol-6(su1006) on the plasmid pRF4 was co-injected with the plasmid to be tested for masculinization in order to identify transformed animals among the F1 progeny of these animals (based on their Rol phenotype). When possible, F2 Rol animals were picked to establish stable lines carrying heritable extrachromosomal arrays.

To assess whether non-masculinized Rol transgenic animals contained both co-injected plasmids, individual animals that had been examined by Nomarski optics $(400 \times)$ for masculinization were analyzed by single worm PCR using a primer (MP10) specific for the vector carrying the her-1-derived construct and a primer specific for her-1 (MP6) (Williams et al. 1992). All Rol cotransformants tested also were found to contain the co-injected her-1-derived construct.

To obtain lines with chromosomally integrated constructs, young adult hermaphrodites carrying an array were subjected to $\gamma$-irradiation ( $3800 \mathrm{rad})$, distributed to individual plates and screened for production of $60-75 \%$ Rol F2 progeny (integrated constructs often show incomplete penetrance of the dominant Rol phenotype), consistent with Mendelian transmission of the rol-6 marker (Krause et al. 1990). Linkage of this marker to a chromosomal gene was then established in appropriate crosses to confirm integration.

Populations of animals containing $l a c Z$ fusions were grown on $\mathrm{Lac}^{-}$bacteria, harvested, and frozen in $2 \%$ paraformaldehyde, $0.1 \%$ glutaraldehyde on dry ice for $5 \mathrm{~min}$. After rapid thawing and rinsing in PBS, the fixed animals were immersed in cold acetone for a further $5 \mathrm{~min}$, air dried, and then stained with $\mathrm{X}$-gal for $4-24 \mathrm{hr}$ at $16-37^{\circ} \mathrm{C}$ (depending on the experiment) as described by Fire et al. (1990).

\section{Heat shock inductions}

Small staged populations of embryos from animals transformed 
with a heat shock promoter construct and rol-6 marker DNA (see text) on NGM plates were heat-shocked in an air incubator for $2 \mathrm{hr}$ at $33^{\circ} \mathrm{C}$ or $1 \mathrm{hr}$ at $37^{\circ} \mathrm{C}$ twice a day. Between heat shocks, animals were grown at $20^{\circ} \mathrm{C}$. Sexual phenotypes of Rol adults were scored by Nomarski microscopy as described by Doniach (1986).

\section{Data base searches}

Nucleic acid and protein sequence data bases at the GenBank on-line e-mail server (Palo Alto, CA) were searched for similarity with her-1 cDNAs and their predicted translation products. The FASTA algorithm (Pearson and Lipman 1988) was used to search GenBank 72.0, GenPept 72.0, and Swiss-Prot 22.0. The BLAST algorithm (Altschul et al. 1990) server at NCBI was used to search Swiss-Prot 23.0, PIR 34.0, GenPept 73.1, GenBank 73.1, and EMBL 32.0. No significant similarities were detected.

\section{Acknowledgments}

We thank Caroline Chamblin and Michael Baron for assistance with the genomic sequencing, Terry Tautz and Debbie Andrew for advice on PCR, Irene Schauer for providing the him- 8 cDNA library and valuable advice, Craig Hunter and Min Han for comments on the manuscript, and Tom Blumenthal, Dennis Dixon, Ed Hedgecock, and Susan White-Harrison for communicating results prior to publication. Some of the strains used in this study were obtained from the Caenorhabditis Genetics Center, which is supported by contract 1RR-4-2-111 between the University of Missouri, Columbia, and the National Institutes of Health Division of Research Resources. M.D.P. was a post-doctoral fellow of the Medical Research Council of Canada and is currently supported by a National Research Service Award from the N.I.H. This work was supported by N.I.H. grants to W.B.W. (HD-11762), C.T. (GM-43333), and A.F. (GM-37706), who is a Rita Allen Foundation Scholar.

The publication costs of this article were defrayed in part by payment of page charges. This article must therefore be hereby marked "advertisement" in accordance with 18 USC section 1734 solely to indicate this fact.

\section{Note}

The sequences reported here, including genomic sequence not shown in Figure 3, have been deposited in the EMBL data library (accession number pending).

\section{References}

Ahmed, A. 1984a. Use of transposon-promoted deletions in DNA sequence analysis. $J$. Mol. Biol. 178: 941-948.

- 1984b. Plasmid vectors for positive galactose-resistance selection of cloned DNA in Escherichia coli. Gene 28: 3743.

Ahringer, J., T.A. Rosenquist, D.N. Lawson, and J. Kimble. 1992. The Caenorhabditis elegans sex determining gene fem-3 is regulated post-transcriptionally. EMBO J. 11: 23032310.

Altschul, S.F., W. Gish, W. Miller, E.W. Myers and D.J. Lipman. 1990. Basic local alignment tool. J. Mol. Biol. 215: 403-410.

Auberger, P., L. Falquerho, J.O. Contreres, G. Pages, G. Le Cam, B. Rossi, and A. Le Cam. 1989. Characterization of a natural inhibitor of the insulin receptor tyrosine kinase: cDNA cloning, purification, and antimitogenic activity. Cell 58: 631640 .
Bektesh, S., K. Van Doren, and D. Hirsh. 1988. Presence of the Caenorhabditis elegans spliced leader on different mRNAs and in different genera of nematodes. Genes \& Dev. 2: 12771283.

Benton, W.D. and R.W. Davis. 1977. Screening $\lambda$ gt recombinant clones by hybridization to single plaques in situ. Science 196: 180-182.

Brenner, S. 1974. The genetics of Caenorhabditis elegans. Genetics 77: 71-94.

Cigarroa, F.G., J.P. Coughlin, P.K. Donahoe, M.F. White, N. Uitvlugt, and D.T. MacLaughlin. 1989. Recombinant human Mullerian inhibiting substance inhibits epidermal growth factor receptor tyrosine kinase. Growth Factors 1: 179-191.

Cline, T.W. 1984. Autoregulatory functioning of a Drosophila gene product that establishes and maintains the sexually determined state. Genetics 107: 231-277.

Doniach, T. 1986. Activity of the sex-determining gene tra-2 is modulated to allow spermatogenesis in the C. elegans hermaphrodite. Genetics 114: 53-76.

Douglass, J., O. Civelli, and E. Herbert. 1984. Polyprotein gene expression: Generation of diversity of neuroendocrine peptides. Annu. Rev. Biochem. 53: 665-715.

Emmons, S. 1988. The genome. In The nematode Caenorhabditis elegans (ed. W.B. Wood), pp. 47-49. Cold Spring Harbor Laboratory, Cold Spring Harbor, New York.

Epstein, H., R. Waterston, and S. Brenner. 1974. A mutant affecting the heavy chain of myosin in Caenorhabditis elegans. J. Mol. Biol. 90: 291-300.

Feinberg, A.P. and B. Vogelstein. 1983. A technique for radiolabelling DNA restriction endonuclease fragments to high specific activity. Anal. Biochem. 132: 6 .

Fire, A. 1986. Integrative transformation of Caenorhabditis elegans. EMBO J. 5: 2673-2680.

Fire, A., S. White-Harrison, and D. Dixon. 1990. A modular set of $l a c Z$ fusion vectors for studying gene expression in Caenorhabditis elegans. Gene 93: 189-198.

Frohmann, M.A., M.K. Dush and G.R. Martin. 1988. Rapid production of full-length cDNAs from rare transcripts: Amplification using a gene-specific oligonucleotide primer. Proc. Natl. Acad. Sci. 85: 8998-9002.

Graham, R.W., D. Jones, and E.P. Candido. 1989. ubiA, the major polyubiquitin locus in Caenorhabditis elegans, has unusual structural features and is constitutively expressed. Mol. Cell. Biol. 9: 268-277.

Hannum, C., D.J. Wilcox, W.P. Arend, F.G. Joslin, D.J. Dripps, P. Heindahl, L.G. Armes, A. Sommer, S.P. Eisenberg, and R.C. Thompson. 1990. Interleukin-1 receptor antagonist activity of a human interleukin-1 inhibitor. Nature 343: 336340.

Hodgkin, J. 1980. More sex-determination mutants of Caenorhabditis elegans. Genetics 96: 649-664.

- 1987. Sex determination and dosage compensation in Caenorhabditis elegans. Annu. Rev. Genetics 21: 133-154.

. 1988. Sexual dimorphism and sex determination. In The nematode Caenorhabditis elegans (ed. W.B. Wood), pp. 243280, Cold Spring Harbor Laboratory, Cold Spring Harbor, New York.

. 1990. Sex determination compared in Drosophila and Caenorhabditis. Nature 344: 721-728.

Hodgkin, J. and Brenner, S. 1977. Mutations causing transformation of sexual phenotype in the nematode $C$. elegans. Genetics 86: 275-287.

Hodgkin, J., H.R. Horvitz, and S. Brenner. 1979. Nondisjunction mutants of the nematode Caenorhabditis elegans. Genetics 91: 67-94.

Hooper, J.E. and M.P. Scott. 1989. The Drosophila patched gene 
encodes a putative membrane protein required for segmental patterning. Cell 59: 751-765.

Horvitz, H. and P. Sternberg. 1991. Multiple intercellular signalling systems control the development of Caenorhabditis elegans vulva. Nature 351: 535-541.

Hunter, C.P. and W.B. Wood. 1990. The tra-1 gene determines sexual phenotype cell-autonomously in C. elegans. Cell 63: 1193-1204.

- 1992. Evidence from mosaic analysis of the masculinizing gene her-1 for cell interactions in C. elegans sex determination. Nature 355: 551-555.

Ingham, P.W., A.M. Taylor, and Y. Nakano. 1991. Role of the Drosophila patched gene in positional signalling. Nature 353: $184-187$.

Kimble, J., L. Edgar, and D. Hirsh. 1984. Specification of male development in Caenorhabditis elegans: The fem genes. Dev. Biol. 105: 234-239.

Kornfeld, R. and S. Kornfeld. 1985 Assembly of asparaginelinked oligo saccharides. Annu. Rev. Biochem 54: 631-664.

Kozak, M. 1983. Comparison of initiation of protein synthesis in procaryotes, eucaryotes, and organelles. Microbiol. Rev. 47: 1-45.

Krause, M. and D. Hirsh. 1987. A trans-spliced leader sequence on actin mRNA in C. elegans. Cell 49: 753-761.

Krause, M., M. Wild, B. Rosenzweig, and D. Hirsh. 1989. Wildtype and mutant actin genes in Caenorhabditis elegans. I. Mol. Biol. 208: 381-392.

Krause M., A. Fire, S.W. Harrison, J. Priess, and H. Weintraub. 1990. CeMyoD accumulation defines the body wall muscle cell fate during Caenorhabditis elegans embryogenesis. Cell 63: 907-919.

Kuwabara, P.E. and J. Kimble. 1992. Molecular genetics of sex determination in C. elegans. Trends Genet. 8: 164-168.

Kuwabara, P.E., P.G. Okkema, and J. Kimble. 1992. tra-2 encodes a membrane protein and may mediate cell communication in the Caenorhabditis elegans sex determination pathway. Mol. Biol. Cell 3: 461-473.

Lee, J.J., D.P. von Kessler, S. Parks, and P.A. Beachy. 1992. Secretion and localized transcription suggest a role in positional signalling for products of the segmentation gene hedgehog. Cell 71: 33-50.

Loh, E.Y., J.F. Elliott, S. Cwirla, L.L. Lanier, and M.M. Davis. 1989. Polymerase chain reaction with single-sided specificity: Analysis of T cell receptor delta chain. Science 243: 217220.

Madl, J.E. and R.K. Herman. 1979. Polyploids and sex determination in Caenorhabditis elegans. Genetics 93: 393-402.

Mello, C.C., J.M. Kramer, D. Stinchcomb, and V. Ambros. 1991. Efficient gene transfer in C. elegans: Extrachromosomal maintenance and integration of transforming sequences. EMBO I. 10: 3959-3970.

Melton, D.A., P.A. Kreig, M.R. Rebagliati, T. Maniatis, K. Zinn, and M.R. Green. 1984. Efficient in vitro synthesis of biologically active RNA and RNA hybridization probes from plasmids containing a bacteriophage SP6 promoter. Nucleic Acids Res. 12: 7035-7056.

Miller, L., J. Plenefisch, L. Casson, and B. Meyer. 1988. xol-1: a gene that controls the male modes of both sex determination and $\mathrm{X}$ chromosome dosage compensation in C. elegans. Cell 55: 167-183.

Nakano, Y., I. Guerrero, A. Hidalgo, A. Taylor, J.R.S. Whittle, and P.W. Ingham. 1989. A protein with several possible membrane-spanning domains encoded by the Drosophila segment polarity gene patched. Nature 341: 508-513.

Nigon, V. 1951. Polyploidie experimentale chez un nematode libre, Rhabditis elegans, Maupas. Biol. Bull. Fr. Belg. 95:
$187-225$

Nusbaum, C. and B. Meyer. 1989. The Caenorhabditis elegans gene $s d c-2$ controls sex determination and dosage compensation in XX animals. Genetics 122: 579-593.

Okkema, P.G. and J. Kimble. 1991. Molecular analysis of tra-2, a sex determining gene in C. elegans. EMBO J. 10: 171-176.

Peabody, D.S. and P. Berg. 1986. Termination-reinitiation occurs in the translation of mammalian cell mRNAs. Mol. Cell. Biol. 6: 2695-2703.

Pearson, W.R. and D.J. Lipman. 1988. Improved tools for biological sequence comparison. Proc. Natl. Acad. Sci. 85: 2444-2448.

Preiss, J.R. and J.N. Thomson. 1987. Cellular interactions in early C. elegans embryos. Cell 48: 241-250.

Sambrook, J., E.F. Fritsch, and T. Maniatis. 1989. Molecular cloning: A laboratory manual, 2nd ed. Cold Spring Harbor Laboratory Press, Cold Spring Harbor, New York.

Sanger, F., S. Nicklen, and A. R. Coulson. 1977. DNA sequencing with chain-terminating inhibitors. Proc. Natl. Acad. Sci. 74: 5463-5467.

Schauer, I. and W.B. Wood. 1990. Early C. elegans embryos are transcriptionally active. Development 110: 1303-1317.

Schnabel, R. 1991. Cellular interactions involved in the determination of the early C. elegans embryo. Mech. Dev. 34: 85100.

Seydoux, G. and I. Greenwald. 1989. Cell autonomy of lin-12 function in a cell fate decision in C. elegans. Cell 57: 12371245.

Sigurdson, D.C., R.K. Herman, C.A. Horton, C.K. Kari, and S.E. Pratt. 1986. An X-autosome fusion chromosome of Caenorhabditis elegans. Mol. Gen. Genet. 202: 212-218.

Spence, A.M., A. Coulson, and J. Hodgkin. 1990. The product of fem-1, a nematode sex determining gene, contains a motif found in cell cycle control proteins and receptors for cellcell interactions. Cell 60: 981-990.

Stringham, E.G., D.K. Dixon, D. Jones, and E.P.M. Candido. 1992. Temporal and spatial expression patterns of the small heat-shock (HSP16) genes in transgenic Caenorhabditis elegans. Mol. Biol. Cell 3: 221-233.

Sulston, J. and J. Hodgkin. 1988. Methods. In The nematode Caenorhabditis elegans (ed. W.B. Wood), pp. 587-606. Cold Spring Harbor Laboratory, Cold Spring Harbor, New York.

Sulston, J.E., E. Schierenberg, J.G. White, and J.N. Thomson. 1983. The embryonic cell lineage of the nematode Caenorhabditis elegans. Dev. Biol. 100: 64-119.

Trent, C., N. Tsung, and H.R. Horvitz. 1983. Egg-laying defective mutants of the nematode Caenorhabditis elegans. Genetics 104: 619-647.

Trent, C., W.B. Wood, and H.R. Horvitz. 1988. A novel dominant transformer allele of the sex-determining gene her-1 of Caenorhabditis elegans. Genetics 120: 145-157.

Trent, C., B. Purnell, S. Gavinski, J. Hageman, C. Chamblin, and W.B. Wood. 1991. Sex-specific transcriptional regulation of the $C$. elegans sex-determining gene her-1. Mech. Dev. 34: 43-55.

Triantaphyllou, A.C. 1973. Environmental sex determination of nematodes in relation to pest management. Annu. Rev. Phytopathol. 11: 441-462.

Villeneuve, A.M. and B.J. Meyer. 1987. sdc-1: A link between sex determination and dosage compensation in $C$. elegans. Cell 48: 25-37.

1990. The regulatory hierarchy controlling sex determination and dosage compensation in Caenorhabditis elegans. Adv. Genet. 27: 117-188.

von Heijne, G. 1986. A new method for predicting signal sequence cleavage sites. Nucleic Acids Res. 14: 4683-4690. 
Perry et al.

Waring, D. and C. Kenyon. 1990. Selective silencing of the cell communication influences anterioposterior pattern formation in C. elegans. Cell 60: 123-131.

Williams, B.D., B. Schrank, C. Huynh, R. Shownkeen, and R.H. Waterston. 1992. A genetic mapping system in Caenorhabditis elegans based on polymorphic sequence tagged sites. Genetics 131: 609-624.

Wood, W.B. 1991. Evidence from reversal of handedness in $C$. elegans embryos for early cell interactions determining cell fates. Nature 349: 536-538.

Zarkower, D. and J. Hodgkin. 1992. Molecular analysis of the $C$. elegans sex determinating gene tra-1. Cell 70: 237-249. 


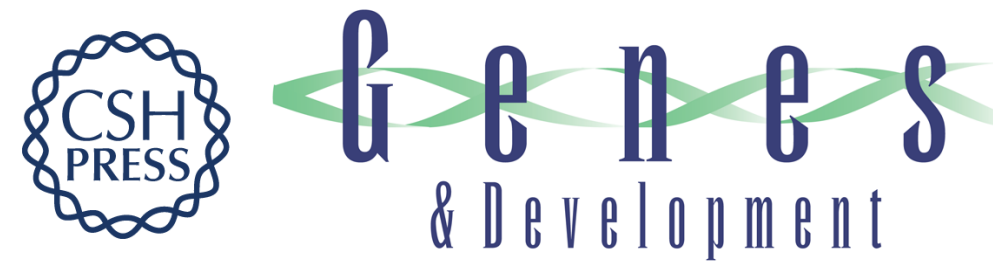

\section{Molecular characterization of the her-1 gene suggests a direct role in cell signaling during Caenorhabditis elegans sex determination.}

M D Perry, W Li, C Trent, et al.

Genes Dev. 1993, 7:

Access the most recent version at doi:10.1101/gad.7.2.216

References This article cites 69 articles, 22 of which can be accessed free at:

http://genesdev.cshlp.org/content/7/2/216.full.html\#ref-list-1

License

Email Alerting

Service

Receive free email alerts when new articles cite this article - sign up in the box at the top right corner of the article or click here.

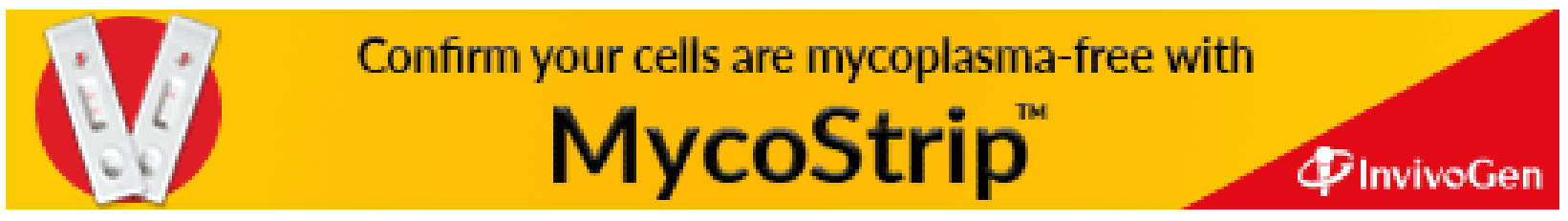

